\title{
Cypermethrin induced stress and changes in growth of freshwater fish Oreochromis niloticus
}

\author{
Rajib Majumder $\cdot$ Anilava Kaviraj $®$
}

Received: 13 November 2016/ Accepted: 29 March 2017/Published online: 7 April 2017

(C) The Author(s) 2017. This article is an open access publication

\begin{abstract}
Bioassays were conducted with technical grade and commercial formulation of cypermethrin using freshwater fish Oreochromis niloticus as the test fish. The technical grade cypermethrin contained $92 \%$ active ingredient (a.i.) and the commercial formulation was an emulsified concentrate (EC) containing $10 \%$ a.i. (10\% EC). Based on the actual concentration in water $(2 \mathrm{~h})$, the commercial formulation was found to be more acutely toxic to $O$. niloticus $\left(96-\mathrm{h} \quad \mathrm{LC}_{50}=4.85 \mu \mathrm{g} / \mathrm{L}\right.$ ) than the technical grade cypermethrin (96-h $\left.\mathrm{LC}_{50}=9.74 \mu \mathrm{g} / \mathrm{L}\right)$. Exposure to sub-lethal concentrations $(1.25,2.5 \mu \mathrm{g} / \mathrm{L})$ of commercial cypermethrin for $96 \mathrm{~h}$ produced stress on the fish, which was evident from the reduction of hepatic glycogen, reduction in the activities of alkaline phosphatase, acetylcholinesterase and catalase in liver and elevation of plasma glucose level and activities of hepatic acid phosphatase, aspartate aminotransferase and alanine aminotransferase. Exposure to these concentrations of cypermethrin for 14-28 days produced anaemia in fish. Long-term exposure (90 days) of the fish to these concentrations reduced the growth and deposition of protein and lipid in the body of fish as compared to control.It is concluded from this study that even minute concentration $(1.25 \mu \mathrm{g} / \mathrm{L})$ of cypermethrin $(10 \% \mathrm{EC})$ in water can produce stress on fish. Long term exposure to such concentration of cypermethrin may also affect growth of the fish.
\end{abstract}

Keywords Pesticide $\cdot$ Toxicity $\cdot$ Tilapia $\cdot \mathrm{LC}_{50} \cdot$ Enzymes $\cdot$ Growth

\section{Introduction}

Cypermethrin is a 4th generation halogenated type II pyrethroid (Kaviraj and Gupta 2014) and is extensively used in tropical countries to control insect pests of cotton, cabbage, okra, brinjal, sugarcane, wheat, sunflower and many other crops. As a result, cypermethrin has been the centre of attention of many researches dealing with susceptibility of fish to agricultural run-offs. Type II pyrethroids are extensively used for pest management because of their relatively low toxicity to birds and mammals. But information on the toxicity of these pesticides to non-target aquatic organisms is scarce. Cypermethrin has already been reported as highly toxic to fish (Kumar et al. 2007; Saha and Kaviraj 2008). Sporadically, it has also been reported that the toxicity of cypermethrin to fish varies with stereochemical structure (Polat et al. 2002), mixtures of their isomers (Yilmaz et al. 2004) and formulation.

R. Majumder · A. Kaviraj $(\bowtie)$

Department of Zoology, University of Kalyani, Kalyani, W.B. 741235, India

e-mail: akaviraj@gmail.com

R. Majumder

Department of Zoology, Vivekananda Mahavidyalaya, Hooghly, W.B. 712405, India 
Commercial formulations of cypermethrin have always been found to be more toxic than its active ingredient (Demetrio et al. 2014; Majumder and Kaviraj 2015) because of inert ingredients added to the commercial formulations of pesticides to improve their efficiency in field conditions (Puglis and Boone 2011).

Emulsified concentrate (EC), with 10-20\% active ingredients, is the most common formulation of cypermethrin being marketed in India. Composition of inert synergists added to these formulations and their contribution to the toxicity of cypermethrin to non-target aquatic organisms are not properly known. Lethal concentrations of different formulations of cypermethrin to fish, reported so far, are based mostly on the nominal concentration of cypermethrin. In this study we determined lethal concentrations of both chemically pure (technical grade) and commercial formulation of cypermethrin to freshwater fish Oreochromis niloticus based on nominal as well as actual concentration of cypermethrin measured after $2 \mathrm{~h}$ of exposure. Comparison of the data generated was helpful to evaluate impact of inert ingredients, if any, onthe toxicity of the commercial formulation of cypemethrin to fish. Since liver is the main site of detoxification of toxicants entering into the body, researchers have made efforts to detect stress of cypermethrin on fish from the activities of hepatic enzymes related to various metabolic pathways (Tiwari et al. 2012; Adeyemi et al. 2014). Reviews by Kaviraj and Gupta (2014) have documented the effects of cypermethrin on liver glycogen, activities of alkaline and acid phosphatase, activities of enzymes related to nitrogen metabolism and lipid peroxidation of liver. Changes in haematological profile have also been used as biomarkers of cypermethrin toxicity to fish (Vani et al. 2012; Ojutiku et al. 2013). However, the effects of cypermethrin on the growth of fish are rather poorly documented (Carriquiriborde et al. 2007). Although the toxic potential of commercial cypermethrin (10\% EC) gradually decreases once it is exposed to light (Saha and Kaviraj 2009a), long-term exposure (60 days) to sub-lethal concentration of this pesticide has been found to reduce the growth of the catfish Heteropneustes fossilis (Saha and Kaviraj 2013). A comprehensive study on the acute toxicity and the effects of sub-lethal concentrations of cypermethrin on the biochemical parameters as well as the growth of fish is lacking.

Oreochromis niloticus is a freshwater fish. Although the species is exotic to India, it is widely cultured throughout the country because of its capacity to adapt to local conditions and tolerance to a wide variety of environmental conditions. The main objectives of the present study were to determine the stress produced by sub-lethal concentrations of commercial cypermethrin $(10 \% \mathrm{EC})$ on $O$. niloticus and the subsequent impact of the pesticide on growth of the fish. Accordingly, we first determined the acute toxicity of technical grade cypermethrin containing $92 \%$ active ingredient (92\% a.i.) and an emulsified concentrate containing $10 \%$ active ingredient (10\% EC) on $O$. niloticus based on both nominal and actual concentrations of cypermethrin in water and then evaluated the degree of difference in toxicity between the two forms of cypermethrin. Detailed studies on the stress and growth of the fish, however, were carried out with sub-lethal concentrations of an emulsified concentrate (10\% EC) of cypermethrin because this form is used in agricultural fields.

\section{Materials and methods}

\section{Experimental design}

Four experiments were performed in this study. These included acute toxicity bioassay to determine lethal concentrations of cypermethrin to $O$. niloticus and experiments with sub-lethal concentrations of cypermethrin (10\% EC) on biochemical parameters ( $96 \mathrm{~h}$ ), haematological parameters (28 days) and growth of $O$. niloticus (90 days).

Specimens of $O$. niloticus (mean length $4.61 \pm 0.24 \mathrm{~cm}$ and mean weight $2.64 \pm 0.16 \mathrm{~g}$ ) were obtained from Kulia fish farm, Kalyani, West Bengal, and were acclimatized to the test conditions for $96 \mathrm{~h}$ before use. During acclimatization, the fish were fed a balanced diet containing $30 \%$ crude protein formulated in the laboratory (Table 1). Proximate compositions of the ingredients and the diet were determined by AOAC method (Helrich1990). Technical grade cypermethrin (92\% active ingredient of $(R S)$ - $\alpha$-cyano-3-phenoxybenzyl (1RS)-cis,trans-3-(2,2-dichlorovinyl)-2,2-dimethyl cyclopropane carboxylate) was obtained from Krishi Rasayan Group of Companies, Kolkata-700020 (India), and the emulsified concentrate (10\% EC) of cypermethrin was procured under the brand name Ustaad ${ }^{\circledR}$ from the United Phosphorus Ltd., Vapi-396195, Gujarat. Deep tube-well water stored in an overhead tank (temperature $31 \pm 3{ }^{\circ} \mathrm{C}$, pH $7.2 \pm 0.1$; free $\mathrm{CO}_{2}$ $3.37 \pm 0.31 \mathrm{mg} / \mathrm{L}$; dissolved oxygen $6.5 \pm 0.2 \mathrm{mg} / \mathrm{L}$; total alkalinity $123.28 \pm 3.37 \mathrm{mg} / \mathrm{L}$ as $\mathrm{CaCO}_{3}$; total hardness $141.44 \pm 11.01 \mathrm{mg} / \mathrm{L}$ as $\mathrm{CaCO}_{3}$ ) was used as the test medium in all experiments. 
Table 1 Proximate composition of the ingredients and the experimental diet

\begin{tabular}{|c|c|c|c|c|c|c|}
\hline \multirow[t]{2}{*}{ Ingredients used for formulation } & \multicolumn{5}{|c|}{ Proximate composition ( $\%$ dry matter) } & \multirow{2}{*}{$\begin{array}{l}\text { Proportion used in formulation } \\
(\%)\end{array}$} \\
\hline & $\begin{array}{l}\text { Crude } \\
\text { protein }\end{array}$ & $\begin{array}{l}\text { Crude } \\
\text { lipid }\end{array}$ & $\begin{array}{l}\text { Crude } \\
\text { fibre }\end{array}$ & Moisture & Ash & \\
\hline Rice bran & 11.96 & 10.8 & 16.3 & 7.46 & 8.73 & 38.74 \\
\hline Mustard oil cake & 31.63 & 12.6 & 8.3 & 7.58 & 9.55 & 38.74 \\
\hline Fishmeal & 65.98 & 13.6 & 3.1 & 13.62 & 9.5 & 20.52 \\
\hline Vitamin premix $^{\mathrm{a}}$ & - & - & - & - & - & 1.0 \\
\hline Mineral premix ${ }^{b}$ & - & - & - & - & - & 1.0 \\
\hline $\begin{array}{l}\text { Formulated diet (dry matter: } \\
\quad 94 \% \text { ) }\end{array}$ & 30.29 & 4.98 & 11.29 & 6.0 & 12.21 & \\
\hline
\end{tabular}

a Vitamin mixture (\%): (Ambiplex; Brihans Lab, Pune): Vit $\mathrm{B}_{1}: 7.14$, Vit $\mathrm{B}_{2}: 2.55$, Vit $\mathrm{B}_{6}: 1.02$, VitB ${ }_{12}: 0.012$, biotin: 0.025 , calcium pantothenate: 2.55 , niacin: 76.50 , choline chloride (B4): 10.20

b Mineral mixture (\%): (Agrimin; Glaxo India Ltd, Mumbai): copper 3.12, cobalt: 0.45, magnesium: 21.14, iron: 9.79, iodine: 1.56, zinc: 21.30 , calcium: 30.00 , phosphorous: 8.25

Acute toxicity bioassays

Acute toxicity bioassays were made in $15-\mathrm{L}$ glass aquaria, each holding $10 \mathrm{~L}$ of water and five acclimatized fish. Separate bioassays were made with technical grade (92\% a.i.) and formulation (10\% EC) of cypermethrin. The range of concentrations of cypermethrin used in these bioassays is presented in Table 2. Three replicates were maintained for each concentration including a water control and a solvent control. The solvent control contained $0.1 \mathrm{ml} / \mathrm{L}$ acetone, because acetone was used to dissolve technical grade cypermethrin, and the maximum amount of acetone present in the highest concentration of technical grade cypermethrin tested was less than $0.1 \mathrm{ml} / \mathrm{L}$. The experiment was carried out for $96 \mathrm{~h}$. Mortality of the fish was recorded every $24 \mathrm{~h}$ and the dead fish were removed. No food was provided during the bioassay to avoid the interference of excretory products of the fish with the test chemical. Lethal concentrations of cypermethrin at which 50\% mortality of the fish occurred $\left(\mathrm{LC}_{50}\right)$ and its $95 \%$ confidence limits were estimated for $96 \mathrm{~h}$ from the mortality data using EPA-Probit analysis version 1.5 statistical software based on the probit analysis method of Finney (1971). LC $_{50}$ values between the active ingredient and formulation were compared following the criteria of Mayer and Ellersieck (1986), Schmuck et al. (1994) and Demetrio et al. (2014).

\section{Residue analysis of cypermethrin}

Residue analyses of cypermethrin were made in the samples of water collected from the aquaria used for acute toxicity bioassay. The samples of water were taken in a separating funnel for separation into water and organic phase. The organic phase was extracted with ethyl acetate and the concentration of cypermethrin in the extract,

Table 2 Range of concentrations of cypermethrin $(\mu \mathrm{g} / \mathrm{L})$ used in the experiments

\begin{tabular}{lccc}
\hline Technical (92\% a.i.) & & \multicolumn{2}{l}{ Formulation (10\% EC) } \\
Nominal & Actual $^{\mathrm{a}}$ & & Nominal $^{\text {Actual }^{\mathrm{a}}}$ \\
\hline 0 & 0 & 0 & 0 \\
5 & 4.31 & 1 & 0.92 \\
10 & 8.61 & 3 & 2.77 \\
15 & 12.92 & 5 & 4.61 \\
20 & 17.22 & 7 & 6.45 \\
25 & 21.53 & 9 & 8.30 \\
30 & 25.83 & 14 & 12.91 \\
\hline
\end{tabular}

${ }^{a}$ After $2 \mathrm{~h}$ of exposure 
after centrifugation $(11,200 \mathrm{~g})$ and filtration through a $0.2-\mu \mathrm{m}$ nylon membrane filter, was determined in a gas chromatograph (Agilent 6890N) equipped with a wide bore HP column (HP-5, $30 \mathrm{~m}, 0.32 \mathrm{~mm}$ ID, $0.25 \mu \mathrm{m}$ film thickness), an electron capture detector (ECD) and a 7683 B Series auto-injector. $\mathrm{N}_{2}$ gas was used as a carrier. Concentration of cypermethrin was quantified from the calibration curve prepared from standard cypermethrin concentrations, using ChemStation software. Limit of detection (LOD) and limit of quantification (LOQ) of the instrument were 0.01 and $0.03 \mathrm{ppm}$, respectively. Nominal concentrations $(N)$ used in the experiments and the respective actual concentrations $(A)$ determined by the above method after $2 \mathrm{~h}$ of exposure are presented in Table 2.

Experiments on biochemical parameters

Experiments on biochemical parameters were also made in 15-L glass aquaria, each holding $10 \mathrm{~L}$ of water and five fish. Three sub-lethal concentrations of the cypermethrin formulation used for these experiments were as follows: control $(0.0 \mu \mathrm{g} / \mathrm{L})$, a low dose $(1.25 \mu \mathrm{g} / \mathrm{L})$ and a high dose $(2.25 \mu \mathrm{g} / \mathrm{L})$ of cypermethrin $(10 \% \mathrm{EC})$. The low and high doses of cypermethrin were approximately 25 and $50 \%$ of the $96-\mathrm{h} \mathrm{LC}_{50}$ value of the nominal concentration of cypermethrin $(10 \% \mathrm{EC})$ to $O$. niloticus, respectively. There were three replicates for each concentration. The fish specimens were sampled after $96 \mathrm{~h}$ of exposure, rinsed in deionized water and dried on blotting paper. Blood was collected directly from the heart of the sampled fish with a micro-syringe and was used for glucose estimation. Simultaneously, liver was dissected out from the sampled fish, weighed and homogenized, and the homogenate was used for the analysis of glycogen content, alkaline and acid phosphatase, aspartate and alanine aminotransferase, acetylcholinesterase and catalase activities of the liver. Plasma glucose was determined by the method of Hyvarinen and Nikkila (1962) and liver glycogen was determined by the method of Carroll et al. (1956). Protein in liver tissue was determined by the method of Lowry et al. (1951), while the activities of the enzymes acid and alkaline phosphatase, aspartate and alanine aminotransferase, acetylcholinesterase and catalase were determined, respectively, by the methods of Walter and Schutt (1974), Reitman and Frankel (1957), Ellman et al. (1961) and Luck (1974).

Experiments on haematological parameters

These experiments were also made in 15-L glass aquaria using the same treatments and experimental conditions as described above for the experiment on biochemical parameters. However, the experiment was carried out for 28 days. One half of the fish were sampled from each aquarium at the end of 14 days and the rest were sampled at the end ( 28 days). Blood was collected from the sampled fish by the technique described above and was subjected to the determination of different haematological parameters. Haemoglobin ( $\mathrm{Hb} \%)$ was determined by cyanomethemoglobin method following Dacie and Lewis (1968), packed cell volume (PCV) or haematocrit (Hct) was determined by Wintrobe method or Macromethod (Dacie and Lewis 1968), and total erythrocyte count (TEC) and total leucocyte count (TLC) were determined with Neubauer's improved double haemocytometer using RBC and WBC diluting fluids, respectively.

\section{Experiments on growth}

Bioassays were carried out in outdoor cement vat (diameter $90 \mathrm{~cm}$ and average depth $50 \mathrm{~cm}$ ). Before stocking of fish, each vat was prepared with a 3-cm-thick layer of uncontaminated soil at the bottom and approximately $100 \mathrm{~g}$ cow dung was applied on it. The vats were then filled with water $(400 \mathrm{~L})$ and kept in this condition for 1 month prior to the start of the experiment to ensure the growth of planktons, which serve as natural food for the test fish. Fingerlings of $O$. niloticus were stocked in these experimental vats and acclimatized in this condition for 1 week before the start of the experiments. Thirty fish, irrespective of their sex, were stocked in each vat. Altogether, nine vats were arranged according to randomized block design so that the fingerlings could be reared in three replicates for each of the three test concentrations $(0,1.25$ and $2.50 \mu \mathrm{g} / \mathrm{L})$ of cypermethrin ( $10 \%$ EC). Treatments with cypermethrin were made on day 1 of the experiment (initial treatment). Then $20 \%$ of the test medium was renewed at 10-day interval with a pulse treatment of pesticides at $20 \%$ of the initial nominal concentration. Static renewal bioassay with renewal of the bioassay medium at regular interval is a standard method to compensate loss of water through evaporation, to reduce the possibility 
of depletion of dissolved oxygen in the test medium and to reduce the possibility of loss of toxicant through volatilization and/or adsorption to test vessels (USEPA 2002). The experiment was continued for 90 days. During the experiments, the fish were hand fed the formulated diet (Table 1) twice daily at an interval of $10 \mathrm{~h}$ up to apparent satiation of the fish. Daily survey was made on the behaviour and mortality of the experimental fish. Water samples were collected from each vat every 15 days and dissolved oxygen, free carbon dioxide, temperature, total hardness and total alkalinity of the sampled water were determined by standard method (APHA 1995). All fish from each outdoor vat were sampled at the end of 90 days and the lengths (cm) and weights $(\mathrm{g})$ of the sampled fish were recorded. Three sampled fish from each vat were subjected to biochemical analyses to determine crude protein, crude lipid and ash contents of the fish following the AOAC method (Helrich 1990). Growth was determined by percent increase in weight, specific growth rate (SGR), feed conversion ratio (FCR) and apparent net protein utilization (ANPU) using standard formulae (Bagenal 1978; Castell and Tiews 1980; Adams and Mclean 1985; Steffens 1989).

Statistical methods

The data obtained from the experiments on haematological, biochemical and growth parameters were subjected to single-factor ANOVA followed by least significant difference (LSD) test to verify the significance of difference between treatments at 5\% level of probability (Gomez and Gomez 1984).

\section{Results}

\section{Acute toxicity}

96-h $\mathrm{LC}_{50}$ values of technical grade (92\% a.i.) and formulation (10\% EC) of cypermethrin to O. niloticus are presented in Table 3. The formulation was found to be more toxic to O. niloticus than the technical grade cypermethrin. In both groups, fish exposed to acute doses exhibited abnormal behaviour. Initially, fish showed frequent surfacing, increased opercular movement and faster swimming activity though within 5-9 h of treatment gradual lethargy was noted in their movement. Deposition of thick mucus layer was found in the buccal cavity and gills of exposed fish probably to minimize the irritating effects of toxicant coming in close contact with body. Sign of heavy internal haemorrhage around pharynx was noticed in the dead fish.

Effects of sub-lethal concentrations of cypermethrin

\section{Liver glycogen and plasma glucose}

Changes in liver glycogen and plasma glucose levels of control and cypermethrin (10\% EC)-treated $O$. niloticus are presented in Fig. 1. There was a gradual decrease in hepatic glycogen level from 24 to $96 \mathrm{~h}$ of exposure, while plasma glucose level increased during this period. The effects were dose dependent, with the treatment of $2.5 \mu \mathrm{g} / \mathrm{L}$ cypermethrin showing more acute effects than that of $1.25 \mu \mathrm{g} / \mathrm{L}$ of cypermethrin.

\section{Hepatic enzyme activities}

Effects of cypermethrin on hepatic enzyme activities of $O$. niloticus are summarized in Table 4. Activities of the enzymes alkaline phosphatase, acetylcholinesterase and catalase decreased significantly $(P<0.05)$ in

Table 3 96-h $\mathrm{LC}_{50}$ values ( $\left.\mu \mathrm{g} / \mathrm{L}\right)$ of cypermethrin and 95\% confidence limit (CL) to freshwater teleost Oreochromis niloticus

\begin{tabular}{lllll}
\hline Cypermethrin & Nominal & & \multicolumn{2}{c}{ Actual $(2 \mathrm{~h})$} \\
\cline { 2 - 3 } \cline { 5 - 6 } & $\mathrm{LC}_{50}$ & $95 \% \mathrm{CL}$ & $\mathrm{LC}_{50}$ & $95 \% \mathrm{CL}$ \\
\hline Technical (92\% a.i.) & 10.71 & $8.79-12.75$ & 9.74 & $8.10-11.35$ \\
Formulation (10\% EC) & 5.25 & $4.35-6.16$ & 4.85 & $4.02-5.68$ \\
\hline
\end{tabular}




\section{Cypermethrin $(\mu \mathrm{g} / \mathrm{L})$}

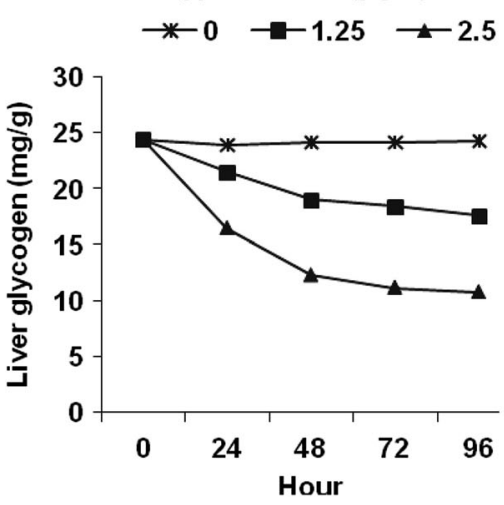

Cypermethrin $(\mu \mathrm{g} / \mathrm{L})$

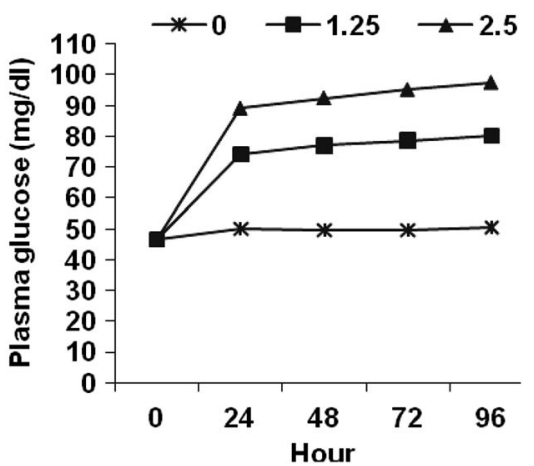

Fig. 1 Effects of cypermethrin (10\% EC) on liver glycogen and plasma glucose of Oreochromis niloticus

Table 4 Changes in activities of hepatic enzymes of $O$. niloticus after 96-h exposure to cypermethrin (10\% EC)

\begin{tabular}{|c|c|c|c|}
\hline Parameter & $0.0 \mu \mathrm{g} / \mathrm{L}$ & $1.25 \mu \mathrm{g} / \mathrm{L}$ & $2.5 \mu \mathrm{g} / \mathrm{L}$ \\
\hline Alkaline phosphatase ${ }^{1}$ & $13.28 \pm 0.07^{\mathrm{a}}$ & $8.95 \pm 0.08^{b}$ & $7.29 \pm 0.07^{\circ}$ \\
\hline Acid phosphatase ${ }^{1}$ & $6.39 \pm 0.06^{\mathrm{a}}$ & $7.67 \pm 0.12^{\mathrm{b}}$ & $8.86 \pm 0.07^{\circ}$ \\
\hline Aspartate aminotransferase ${ }^{2}$ & $2.28 \pm 0.02^{\mathrm{a}}$ & $3.04 \pm 0.04^{\mathrm{b}}$ & $3.58 \pm 0.03^{\mathrm{c}}$ \\
\hline Alanine aminotransferase ${ }^{2}$ & $5.71 \pm 0.02^{\mathrm{a}}$ & $6.98 \pm 0.04^{\mathrm{b}}$ & $9.55 \pm 0.04^{\mathrm{C}}$ \\
\hline Acetylcholinesterase $^{3}$ & $0.73 \pm 0.02^{\mathrm{a}}$ & $0.48 \pm 0.01^{\mathrm{b}}$ & $0.38 \pm 0.02^{\mathrm{c}}$ \\
\hline Catalase $^{4}$ & $13.37 \pm 0.04^{\mathrm{a}}$ & $11.06 \pm 0.09^{\mathrm{b}}$ & $9.36 \pm 0.08^{\mathrm{c}}$ \\
\hline
\end{tabular}

Data are mean $\pm \mathrm{SD}(n=3)$; means with dissimilar superscripts in the same row indicate the least significant difference between the means at $P<0.05$

${ }^{1} \mu \mathrm{g} \mathrm{PNP} / \mathrm{mg}$ tissue protein/30 $\mathrm{min}$

${ }^{2} \mu \mathrm{M}$ pyruvate/mg tissue protein/h

${ }^{3} \mu \mathrm{M}$ acetylthiocholine iodide/mg tissue protein/min

${ }^{4} \mu \mathrm{M} \mathrm{H}_{2} \mathrm{O}_{2}$ decomposed/mg tissue protein/min

cypermethrin treatments as compared to control. The higher the concentration of cypermethrin, the lower the activities of these enzymes. On the contrary, the activities of the enzymes acid phosphatase, aspartate aminotransferase and alanine aminotransferase increased significantly $(P<0.05)$ in both treatments of cypermethrin as compared to control. There were also significant differences in activities between the two sublethal concentrations $(1.25$ and $2.5 \mu \mathrm{g} / \mathrm{L})$ of cypermethrin.

\section{Haematological parameters}

The changes in haematological parameters of $O$. niloticus exposed to control and cypermethrin are summarized in Table 5. The results indicated that TEC, haemoglobin concentration $(\mathrm{Hb}), \mathrm{PCV}$, mean cell volume (MCV), mean cell haemoglobin $(\mathrm{MCH})$ and mean corpuscular haemoglobin concentration (MCHC) decreased significantly $(P<0.05)$ in both sub-lethal concentrations of cypermethrin $(1.25$ and $2.5 \mu \mathrm{g} / \mathrm{L})$ as compared to control. On the other hand, total leucocyte count showed significant elevation in cypermethrin-treated $O$. niloticus than the control. There was no significant difference in these parameters between the exposure periods of 14 and 28 days.

Effects on growth

Long-term exposure (90 days) to sub-lethal concentrations of cypermethrin increased mortality and reduced growth of $O$. niloticus as compared to control. The growth parameters are summarized in Table 6. Fish exposed to $2.5 \mu \mathrm{g} / \mathrm{L}$ cypermethrin showed more reduction in weight gain (\%), SGR, protein efficiency ratio 
Table 5 Changes in haematological parameters of $O$. niloticus exposed to cypermethrin

\begin{tabular}{lllll}
\hline Parameters & Days of exposure & $0.0 \mu \mathrm{g} / \mathrm{L}$ & $1.25 \mu \mathrm{g} / \mathrm{L}$ & $2.5 \mu \mathrm{g} / \mathrm{L}$ \\
\hline Total erythrocyte count $\left(10^{6} / \mathrm{mm}^{3}\right)$ & 14 & $2.81 \pm 0.03^{\mathrm{a}}$ & $2.74 \pm 0.04^{\mathrm{b}}$ & $2.62 \pm 0.03^{\mathrm{c}}$ \\
& 28 & $2.86 \pm 0.05^{\mathrm{a}}$ & $2.68 \pm 0.06^{\mathrm{b}}$ & $2.51 \pm 0.02^{\mathrm{c}}$ \\
Haemoglobin concentration $(\mathrm{g} / \mathrm{dl})$ & 14 & $8.72 \pm 0.05^{\mathrm{a}}$ & $7.77 \pm 0.04^{\mathrm{b}}$ & $7.08 \pm 0.09^{\mathrm{c}}$ \\
& 28 & $8.83 \pm 0.05^{\mathrm{a}}$ & $7.34 \pm 0.05^{\mathrm{b}}$ & $6.74 \pm 0.06^{\mathrm{c}}$ \\
Packed cell volume (\%) & 14 & $25.58 \pm 0.16^{\mathrm{a}}$ & $23.68 \pm 0.07^{\mathrm{b}}$ & $21.99 \pm 0.69^{\mathrm{c}}$ \\
& 28 & $25.67 \pm 0.14^{\mathrm{a}}$ & $22.53 \pm 0.11^{\mathrm{b}}$ & $20.96 \pm 0.21^{\mathrm{c}}$ \\
Mean cell volume (fl/cell) & 14 & $91.05 \pm 1.12^{\mathrm{a}}$ & $86.55 \pm 1.13^{\mathrm{b}}$ & $83.92 \pm 0.64^{\mathrm{c}}$ \\
& 28 & $89.66 \pm 1.26^{\mathrm{a}}$ & $84.18 \pm 1.76^{\mathrm{b}}$ & $83.51 \pm 0.99^{\mathrm{c}}$ \\
Mean cell haemoglobin $(\mathrm{pg} / \mathrm{cell})$ & 14 & $31.04 \pm 0.17^{\mathrm{a}}$ & $28.41 \pm 0.45^{\mathrm{b}}$ & $27.04 \pm 0.25^{\mathrm{b}}$ \\
& 28 & $30.86 \pm 0.58^{\mathrm{a}}$ & $27.43 \pm 0.51^{\mathrm{b}}$ & $26.84 \pm 0.01^{\mathrm{b}}$ \\
Mean corpuscular haemoglobin concentration $(\mathrm{g} / \mathrm{dl})$ & 14 & $34.09 \pm 0.17^{\mathrm{a}}$ & $32.82 \pm 0.24^{\mathrm{b}}$ & $32.22 \pm 0.31^{\mathrm{b}}$ \\
& 28 & $34.41 \pm 0.36^{\mathrm{a}}$ & $32.58 \pm 0.33^{\mathrm{b}}$ & $32.14 \pm 0.40^{\mathrm{b}}$ \\
Total leucocyte count $\left(10^{3} / \mathrm{mm}^{3}\right)$ & 14 & $23.55 \pm 0.13^{\mathrm{a}}$ & $24.74 \pm 0.07^{\mathrm{b}}$ & $25.96 \pm 0.08^{\mathrm{c}}$ \\
& 28 & $23.94 \pm 0.09^{\mathrm{a}}$ & $25.59 \pm 0.15^{\mathrm{b}}$ & $26.86 \pm 0.07^{\mathrm{c}}$ \\
\hline
\end{tabular}

Data are mean $\pm \mathrm{SD}(n=3)$; means with dissimilar superscripts in the same row indicate the least significant difference between the means at $P<0.05$

Table 6 Changes in growth parameters and mortality of $O$. niloticus exposed to cypermethrin (10\% EC) for 90 days

\begin{tabular}{|c|c|c|c|}
\hline Parameters & $0.0 \mu \mathrm{g} / \mathrm{L}$ & $1.25 \mu \mathrm{g} / \mathrm{L}$ & $2.5 \mu \mathrm{g} / \mathrm{L}$ \\
\hline Initial weight (g) & $2.64 \pm 0.16$ & $2.64 \pm 0.16$ & $2.64 \pm 0.16$ \\
\hline Weight gain $(\%)^{1}$ & $128.39 \pm 8.36^{\mathrm{a}}$ & $74.72 \pm 10.89^{\mathrm{b}}$ & $51.79 \pm 9.45^{\mathrm{c}}$ \\
\hline $\mathrm{FCR}^{2}$ & $3.08 \pm 0.21^{\mathrm{a}}$ & $4.19 \pm 0.53^{\mathrm{b}}$ & $4.95 \pm 0.98^{\mathrm{c}}$ \\
\hline SGR $(\% / \text { day })^{3}$ & $0.92 \pm 0.04^{\mathrm{a}}$ & $0.62 \pm 0.07^{\mathrm{b}}$ & $0.46 \pm 0.07^{\mathrm{c}}$ \\
\hline $\mathrm{PER}^{4}$ & $1.09 \pm 0.07^{\mathrm{a}}$ & $0.81 \pm 0.12^{\mathrm{b}}$ & $0.70 \pm 0.12^{\mathrm{c}}$ \\
\hline $\mathrm{HSI}^{5}$ & $1.10 \pm 0.04^{\mathrm{a}}$ & $1.57 \pm 0.09^{\mathrm{b}}$ & $1.83 \pm 0.12^{\mathrm{c}}$ \\
\hline $\operatorname{ANPU}(\%)^{6}$ & $20.85 \pm 1.12^{\mathrm{a}}$ & $13.61 \pm 1.60^{\mathrm{b}}$ & $10.74 \pm 1.54^{\mathrm{c}}$ \\
\hline Mortality (\%) & $4.04 \pm 1.22^{\mathrm{a}}$ & $17.39 \pm 1.26^{\mathrm{b}}$ & $21.75 \pm 1.30^{\mathrm{c}}$ \\
\hline
\end{tabular}

Values are the mean of three replicates $\pm \mathrm{SD}$; means with dissimilar superscripts in the same row indicate the least significant difference between the means at $P<0.05$

${ }^{1}$ Weight gain $(\%)=[\{$ final wt $(\mathrm{g})-$ initial wt $(\mathrm{g})\} /$ initial $\mathrm{wt}(\mathrm{g})] \times 100$

${ }^{2}$ Feed conversion ratio $=$ food given/weight gain

${ }^{3}$ Specific growth rate $(\% /$ day $)=\left\{\left(\log _{\mathrm{e}} W_{2}-\log _{\mathrm{e}} W_{1}\right) / T\right\} \times 100$, where $W_{1}=$ initial body weight $(\mathrm{g}), W_{2}=$ final body weight (g) and $T=$ days of exposure

${ }^{4}$ Protein efficiency ratio $=$ increase in weight of fish (wet weight)/weight of protein in feed (dry weight)

${ }^{5}$ Hepatosomatic index $=[\{$ wet weight of liver $(\mathrm{g})$ without gall bladder $\} /$ wet body weight $] \times 100$

${ }^{6}$ Apparent net protein utilization $(\%)=($ net increase in carcass protein/amount of protein consumed $) \times 100$

(PER) and ANPU than those treated by $1.25 \mu \mathrm{g} / \mathrm{L}$ cypermethrin. FCR and hepatosomatic index (HSI) increased significantly $(P<0.05)$ in fish treated with $2.5 \mu \mathrm{g} / \mathrm{L}$ cypermethrin than in those treated with $1.25 \mu \mathrm{g} / \mathrm{L}$ cypermethrin treatment and control. Proximate compositions of carcass of the sampled fish are presented in Table 7. The results clearly indicated that crude protein, crude lipid and ash contents increased from their initial values. However, the rate of increase was significantly lower in cypermethrin-treated fish in comparison to control. Among the cypermethrin-treated fish, the values reduced with the increase of cypermethrin concentration. 
Table 7 Proximate composition (\% wet weight basis) of carcass of $O$. niloticus exposed to cypermethrin (10\% EC) for 90 days

\begin{tabular}{|c|c|c|c|c|}
\hline & \multirow[t]{2}{*}{ Initial } & \multicolumn{3}{|l|}{ Final } \\
\hline & & $0.0 \mu \mathrm{g} / \mathrm{L}$ & $1.25 \mu \mathrm{g} / \mathrm{L}$ & $2.5 \mu \mathrm{g} / \mathrm{L}$ \\
\hline Crude protein & $11.13 \pm 0.27$ & $15.40 \pm 0.24^{\mathrm{a}}$ & $13.56 \pm 0.24^{\mathrm{b}}$ & $12.43 \pm 0.24^{\mathrm{c}}$ \\
\hline Crude lipid & $2.73 \pm 0.14$ & $4.78 \pm 0.12^{\mathrm{a}}$ & $3.63 \pm 0.14^{\mathrm{b}}$ & $3.22 \pm 1.12^{\mathrm{c}}$ \\
\hline Ash & $1.89 \pm 0.08$ & $3.01 \pm 0.07^{\mathrm{a}}$ & $2.49 \pm 0.06^{\mathrm{b}}$ & $2.29 \pm 0.07^{\mathrm{c}}$ \\
\hline
\end{tabular}

Values are the mean of three replicates $\pm \mathrm{SD}$; means with dissimilar superscripts in the same row indicate the least significant difference between the means at $P<0.05$

\section{Discussion}

Acute toxicity

96-h $\mathrm{LC}_{50}$ values of technical grade (92\% a.i.) and commercial (10\% EC) cypermethrin to $O$. niloticus as observed in the present investigation are, respectively, close to $96-\mathrm{h} \mathrm{LC}_{50}$ values of technical grade (98\%) alpha-cypermethrin to Poecilia reticulata $(9.43 \mu \mathrm{g} / \mathrm{L}$; Yilmaz et al. 2004) and commercial cypermethrin (10\% EC) to freshwater fish Colisa fasciatus $(6.0 \mu \mathrm{g} / \mathrm{L}$; Singh et al. 2010). The present results indicate that the emulsified concentrate (EC) of cypermethrin is more toxic than the technical grade (active ingredient) cypermethrin. This has also been confirmed by the toxicity studies of cypermethrin on various species of invertebrates (Demetrio et al. 2014; Majumder and Kaviraj 2015). Several studies have demonstrated that the inert ingredients added to the formulated products increase its toxicity (Puglis and Boone 2011). Quotient $\left(\mathrm{LC}_{50}\right.$ of $\mathrm{X} / \mathrm{LC}_{50}$ of $\left.\mathrm{Y}\right)$ is used to interpret and compare the acute toxicity data between technical grade $(\mathrm{X})$ and formulation (Y) of pesticides. Mayer and Ellersieck (1986) assumed the formulation as more toxic when the quotient was more than 1, while Schmuck et al. (1994) observed that there was a natural variability of quotient between 0.5 and 2.0 and considered the formulation as more toxic when the quotient was more than 2 . Evaluating the results of the present study, it was revealed that the formulation was more toxic than the technical grade cypermethrin according to the criteria of Mayer and Ellersieck (1986) and Schmuck et al. (1994). Since only one single point $\left(\mathrm{LC}_{50}\right)$ for the concentration-effect function was considered under both criteria, Demetrio et al. (2014) proposed to accept the criteria as valid only when the concentration effect lines were parallel. Log-probit model regression lines for log concentration versus probit values of mortality for O. niloticus following 96-h exposure to technical grade (T) and formulation (F) of cypermethrin were parallel to each other (Fig. 2).

Biochemical parameters

Reduction of hepatic glycogen content in $O$. niloticus due to cypermethrin treatment as observed in the present study is a common symptom of stress exhibited by fish when exposed to type II pyrethroids (Kaviraj and Gupta 2014). Similar effects of cypermethrin have been reported for Clarias batrachus (Begum 2005), H. fossilis (Saha and Kaviraj 2009b) and Ophiocephalus punctatus (Shruti et al. 2011) and Labeo rohita (Tiwari et al. 2012). Carbohydrate serves as the instant source of energy during stress. Accordingly, glycogen of liver is broken down (glycogenolysis) to meet the energy demand raised during cypermethrin stress, resulting in the reduction of hepatic glycogen content. On the other hand, an increase in plasma glucose level due to cypermethrin treatment, as observed in the present study, has also been observed on H. fossilis (Saha and Kaviraj 2009b) and O. niloticus (Firat et al. 2011) probably due to an increase in hepatic glucose-6phosphatase activity which enhances glycogenolysis and glucose synthesis from extrahepatic tissue proteins and amino acids (Firat et al. 2011). Gluconeogenesis is another pathway to increase plasma glucose level during the stress of pesticide to fish (Saravanan et al. 2011). This is initiated by aminotransferase enzymes, which provide strategic links between protein and carbohydrate metabolism to meet the demand of energy under stressed condition (Neelima et al. 2013). Increased activities of hepatic aspartate aminotransferase (AST) and alanine aminotransferase (ALT) as observed in the present study indicate active catabolism of amino acid to meet the immediate energy demand under cypermethrin stress (Kumar et al. 2011). In the first 


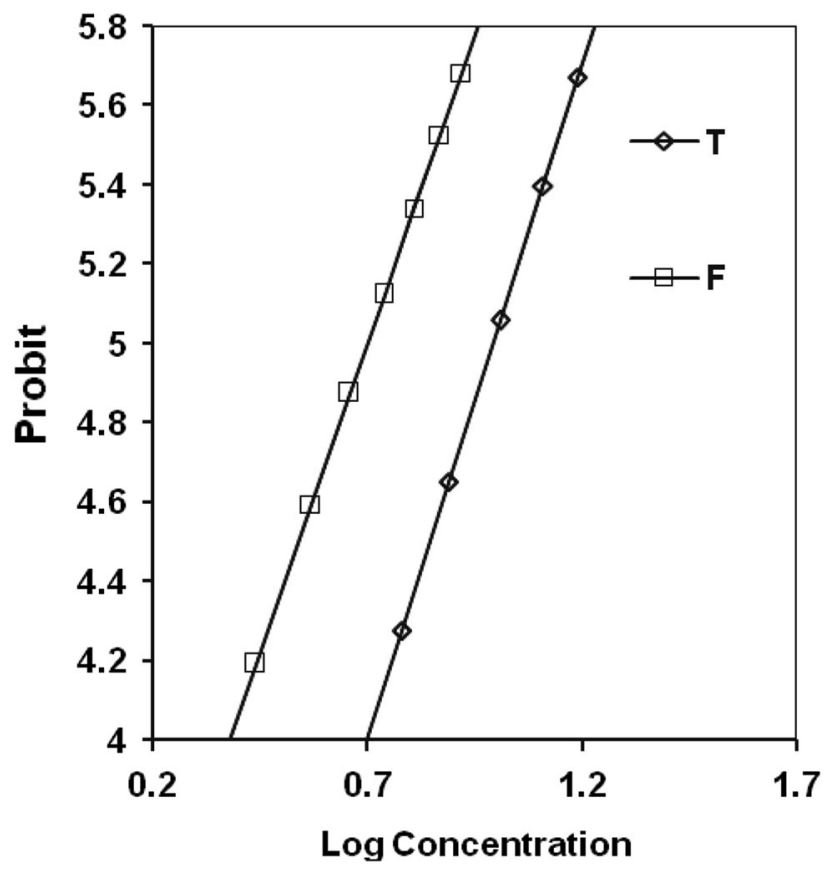

Fig. 2 Log-probit model regression lines for log concentration (actual) versus probit values for Oreochromis niloticus following 96-h exposure to technical grade $(T)$ and formulation $(F)$ of cypermethrin

phase of catabolism, $\alpha$ keto acids are formed through transamination. Gluconeogenesis is promoted by the incorporation of keto acids into tricarboxylic acid (TCA) cycle via active transdeamination (Neelima et al. 2013). Studies on cypermethrin-induced increase in the activities of hepatic AST and ALT in C. batrachus (Begum 2005), Cirrhinus mrigala (Prasanth and Neelagund 2008), Channa punctatus and C. batrachus (Kumar et al. 2011), L. rohita (Tiwari et al. 2012), Catla catla (Vani et al. 2012) and Prochilodus lineatus (Loteste et al. 2013) indicate that fish utilize amino acids to overcome the stress of cypermethrin.

Changes in glucose metabolism were also linked with the activities of hepatic alkaline phosphatase, which were decreased in cypermethrin-treated $O$. niloticus as compared to control. Similar effects of cypermethrin on alkaline phosphatase activities were found in the liver of Heterobranchus bidorsalis (Gabriel et al. 2011), H. fossilis (Saha and Kaviraj 2009b) and L. rohita (Tiwari et al. 2012). Liver alkaline phosphatase promotes glycogen synthesis by inactivating the enzyme phosphorylase. Reduced activities of hepatic alkaline phosphatase may lead to the breakdown of glycogen in order to get necessary energy to overcome the stress. Some researchers reported increased activities of alkaline phosphatase in the serum of fish exposed to cypermethrin, which might be due to the efflux of enzymes from the liver into bloodstream (Firat et al. 2011; Meenambal et al. 2012). On the other hand, the activity of acid phosphatase was elevated in cypermethrin-exposed $O$. niloticus as compared to control. These results are in agreement with the findings of Kumar et al. (2014) on C. batrachus. Acid phosphatase is a lysosomal enzyme that hydrolyses the ester linkage of phosphate esters and cause autolysis of cell after its death. Increased acid phosphatase activity may be due to hepatocellular damages in $O$. niloticus exposed to cypermethrin.

Acetylcholinesterase (AChE) is distributed in synaptic region and induces nerve impulse propagation by converting acetylcholine into acetic acid and choline. Inhibition of this enzyme can cause hyperexcitability. This reaction was evident in the acute toxicity experiment with cypermethrin in the present study. Cypermethrin probably interacts with the hydrophobic aromatic surface region of acetylcholinesterase and inhibits the activities of this enzyme as observed in L. rohita (Tiwari et al. 2012), C. batrachus (Kumar et al. 2014), Channa striatus (Ahmed et al. 2015) and Cyprinus carpio (Neelima et al. 2015).

Cypermethrin also produces oxidative stress in fish. This was evident from the decreased activity of catalase in the liver of $O$. niloticus exposed to sub-lethal concentrations of cypermethrin, as observed in the present study. Catalase is an enzymatic antioxidant. Reactive oxygen species (ROS) like superoxide anion, hydrogen peroxide and hydroxyl radicals are formed in fish upon exposure to pollutants. Catalase scavenges 
reactive oxygen species, converts them into less reactive species and prevents lipid peroxidation. Accordingly, the activity of malondialdehyde (MDA) is increased and that of catalase is decreased as oxidative defense in fish (Marigoudar et al. 2013; Kaviraj and Gupta 2014). Catalase activity thus serves as a potential oxidative stress biomarker in fish toxicity studies. Tripathi and Bandooni (2011) observed decreased activity of catalase in the liver of $C$. batrachus treated with alphamethrin, a racemic mixture of two isomers of cypermethrin. Cypermethrin-induced reduction in the catalase activity of spermatozoa has also been observed in Oncorhynchus mykiss (Kutluyer et al. 2016).

Haematological parameters

Decline in total erythrocyte count, $\mathrm{Hb}$ content, PCV and MCHC values as observed in the present study is an indication of anaemia. Anaemia is probably caused by the inhibition of erythropoiesis and chemosynthesis as well as the destruction of erythrocytes (Adhikari et al. 2004; Jee et al. 2005; Akinrotimi et al. 2012). In addition, WBC is liberated from the spleen into the blood to counter the cypermethrin-induced stress (Akinrotimi et al. 2012), resulting in an increase in leucocyte count (Adhikari et al. 2004; Ojutiku et al. 2013) as also observed in the present study.

Effects on growth and biochemical composition

Results of the present study indicated that the growth of $O$. niloticus is reduced when exposed to sub-lethal concentrations of cypermethrin for 90 days. This was due to poor efficiency in feed conversion, net protein utilization and subsequent poor deposition of protein and lipid in the muscle. There are evidence that cypermethrin can reduce the protein level of serum (Vani et al. 2012; Kannan et al. 2014), gills and liver (Begum 2005), muscle and kidneys (Begum 2007) in several species of fish. Gijare et al. (2011) also found that the lipid content was decreased in $O$. punctatus due to cypermethrin treatment. The toxic impact of cypermethrin is quickly removed from water (Saha and Kaviraj 2009a). But the results of the present study indicate that the stress produced by $1.25-2.5 \mu \mathrm{g} / \mathrm{L}$ cypermethrin $(10 \% \mathrm{EC})$ on biochemical and haematological parameters is carried and reflected on feed conversion and deposition of protein.

\section{Conclusion}

It is concluded from the present study that cypermethrin (10\% EC) is highly toxic to O. niloticus. Concentration of cypermethrin as low as $1.25 \mu \mathrm{g} / \mathrm{L}$ is capable of inducing changes in biochemical and haematological parameters of the fish after short-term exposure.These changes are indication of stress on the fish. The stress also affects growth of the fish, if itis exposed to cypermethrin for long period.

Acknowledgements Partial research grants received from the University of Kalyani through the Department of Science and Technology-Promotion of University Research and Scientific Excellence (DST-PURSE) and Personal Research Grant are thankfully acknowledged.

\section{Compliance with ethical standards}

Conflict of interest There is no conflict of interest.

Open Access This article is distributed under the terms of the Creative Commons Attribution 4.0 International License (http:// creativecommons.org/licenses/by/4.0/), which permits unrestricted use, distribution, and reproduction in any medium, provided you give appropriate credit to the original author(s) and the source, provide a link to the Creative Commons license, and indicate if changes were made.

\section{References}

Adams SM, McLean RB (1985) Estimation of the large mouth bass, Micropterus salmoides Lacepede, growth using the liver somatic index physiological variables. J Fish Biol 26:111-126 
Adeyemi JA, Adewale OO, Oguma AY (2014) Mortality, oxidative stress and hepatotoxicities in juvenile African catfish, Clarias gariepinus Burchell, exposed to lead and cypermethrin. Bull Environ Contam Toxicol 92:529-533

Adhikari S, Sarkar B, Chatterjee A, Mahapatra CT, Ayyappan S (2004) Effects of cypermethrin and carbofuran on certain haematological parameters and prediction of their recovery in a freshwater teleost, Labeo rohita (Hamilton). Ecotoxicol Environ Saf 58:220-226

Ahmed O, Mastan SA, Rabiabanu S, Indira P (2015) Sub lethal effect of cypermethrin on acetylcholinesterase (AChE) activity and acetylcholine (Ach) content in selected tissues of Channa striatus (Bloch.). J Toxicol Environ Health Sci 7(4):31-37

Akinrotimi OA, Gabriel UU, Ariweriokuma SV (2012) Haematotoxicity of cypermethrin to African catfish (Clarias gariepinus) under laboratory conditions. J Environ Eng Technol 1(2):13-19

APHA (American Public Health Association) (1995) Standard methods for the examination of water and wastewater. American Public Health Association, American Water Works association and Water Pollution Control Federation, Washington, DC

Bagenal T (1978) Methods for assessment of fish production in fresh water, 3rd edn. Blackwell Scientific Publication, Oxford

Begum G (2005) In vivo biochemical changes in liver and gill of Clarias batrachus during cypermethrin exposure and following cessation of exposure. Pestic Biochem Phys 82(3):185-196

Begum G (2007) Cypermethrin induced biochemical perturbations in freshwater fish Clarias batrachus at sublethal exposure and after released into freshwater. Drug Chem Toxicol 30:55-65

Carriquiriborde P, Díaz J, Mugni H, Bonetto C, Ronco AE (2007) Impact of cypermethrin on stream fish populations under field use in biotech-soybean production. Chemosphere 68:613-621

Carroll NV, Longley RW, Roe JH (1956) The determination of glycogen in liver and muscle by use of anthrone reagent. J Biol Chem 220:583-593

Castell JD, Tiews K (1980) Report of the EIFAC, IUNS and ICES working Group on the standardization of methodology in fish nutrition research. EIFAC Technical Paper 36

Dacie JV, Lewis SM (1968) Practical haematology, 4th edn. Churchill, London

Demetrio PM, Bonetto C, Ronco AE (2014) The effect of cypermethrin, chlorpyrifos and glyphosate active ingredients and formulations on Daphnia magna (Straus). Bull Environ Contam Toxicol 93:268-273

Ellman GL, Courtney KD, Andres V Jr, Featherstone RM (1961) A new and rapid colorimetric determination of acetylcholinesterase activity. Biochem Pharmacol 7:88-95

Finney DJ (1971) Probit analysis. Cambridge University Press, London

Firat Ö, Cogum HY, Yüzereroğlu TA, Gök G, Firat Ö, Kargin F, Kötemen Y (2011) A comparative study on the effects of a pesticide (cypermethrin) and two metals (copper, lead) to serum biochemistry of Nile tilapia, Oreochromis niloticus. Fish Physiol Biochem 37:657-666

Gabriel UU, Jack IR, Egobueze E, Edori OS (2011) Impact of cypermethrin on selected enzymes in tissues of Heterobranchus bidorsalis. West Afr J Appl Ecol 18:121-127

Gijare SS, Raja IA, Tantarpale VT, Kulkarni KM (2011) Lipid changes in the freshwater fish Ophiocephalus punctatus exposed to synthetic pyrethroid cypermethrin. Biosci Biotechnol Res Commun 4(1):52-54

Gomez KA, Gomez AA (1984) Statistical procedures for agricultural research, 2nd edn. Wiley Interscience, New York

Helrich K (1990) Official methods of analyses, vol I, 15th edn. Association of Official Analytical Chemists (AOAC), Washington, DC

Hyvarinen A, Nikkila E (1962) Specific determination of blood glucose with $O$-toluidine. Clin Chim Acta 7:140

Jee JH, Masroor F, Kang JC (2005) Responses of cypermethrin induced stress in haematological parameters of Korean rock fish, Sebastes schlegeli (Hilgendorf). Aquac Res 36:898-905

Kannan M, Muthusamy P, Venkatachalam U (2014) Response of synthetic pyrethroid cypermethrin (10\% EC) induced stress in biochemical and haematological parameters of Indian major carp Catla catla (Hamilton, 1822). World J Pharm Res 3(4):1976-1996

Kaviraj A, Gupta A (2014) Biomarkers of type II synthetic pyrethroid pesticides in freshwater fish. BioMed Res Int. Article ID 928063. doi:10.1155/2014/928063

Kumar A, Sharma B, Pandey RS (2007) Preliminary evaluation of the acute toxicity of cypermethrin and $\lambda$-cyhalothrin to Channa punctatus. Bull Environ Contam Toxicol 79:613-616

Kumar A, Sharma B, Pandey RS (2011) Cypermethrin induced alterations in nitrogen metabolism in freshwater fishes. Chemosphere 83:492-501

Kumar A, Sharma B, Pandey RS (2014) $\lambda$-Cyhalothrin and cypermethrin induce stress in the freshwater muddy fish, Clarias batrachus. Toxicol Environ Chem 96(1):136-149

Kutluyer F, Benzer F, Erişir M, Öğretmen F, Inanan BE (2016) The in vitro effect of cypermethrin on quality and oxidative stress indices of rainbow trout Oncorhynchus mykiss spermatozoa. Pestic Biochem Phys 128:63-68

Loteste A, Scagnetti J, Simoniello MF, Campana M, Parma MJ (2013) Hepatic enzymes activity in the fish Prochilodus lineatus (Valenciennes, 1836) after sublethal cypermethrin exposure. Bull Environ Contam Toxicol 90:601-604

Lowry OH, Rosebrough NJ, Farr AL, Randall RJ (1951) Protein measurement with the folin-phenol reagent. J Biol Chem 193:265-275

Luck H (1974) Catalase. In: Bergmeyer HU (ed) Methods of enzymatic analysis, 2nd edn. Academic Press, New York, pp $885-890$

Majumder R, Kaviraj A (2015) Variation in acute toxicity between technical grade and commercial formulation of cypermethrin to some non-target freshwater organisms. Int J Curr Res 7(06):16755-16759

Marigoudar SR, Ahmed RN, David M (2013) Ultrastructural responses and oxidative stress induced by cypermethrin in the liver of Labeo rohita. Chem Ecol 29(4):296-308

Mayer FL Jr, Ellersieck MR (1986) Manual of acute toxicity: interpretation and data base for 410 chemicals and 66 species of freshwater animals. US Department of the Interior, Fish and Wildlife Service. Resource Publication 160, Washington, DC 
Meenambal M, Pugazhendy K, Vasantharaja C, Venkatesan S (2012) Ameliorative property of Delonix elata supplementary feed against cypermethrin induced serum biochemical changes in freshwater fish Cyprinus carpio (Linn). J Pharm Res 5(5):2489-2492

Neelima P, Kumar LCA, Rao NG, Rao JCS (2013) Studies on activity levels of aspartate amino transferase (ASAT) and alanine aminotransferase (ALAT) in the tissues of Cyprinus carpio (Linn.) exposed to cypermethrin (25\% EC). Int J Pharm Pharm Sci 5(3):566-570

Neelima P, Rao KG, Rao NG, Jammu CSR (2015) Enzymatic alterations as biomarkers of cypermethrin (25\% EC) toxicity in a freshwater fish, Cyprinus carpio (Linn.). Int J Fish Aquat Stud 3(1):149-158

Ojutiku RO, Asuwaju FP, Ayanda IO, Obande RA, Agbelege OO (2013) Effects of acute toxicity of cypermethrin on some biochemical parameters of juveniles of Clarias gariepinus (Burchell, 1822). Int J Eng Sci Invent 2(3):01-07

Polat H, Erkoç FÜ, Viran R, Koçak O (2002) Investigation of acute toxicity of beta-cypermethrin on guppies Poecilia reticulata. Chemosphere 49:39-44

Prasanth MS, Neelagund SE (2008) Impact of cypermethrin on enzyme activities in the freshwater fish Cirrhinus mrigala (Hamilton). Casp J Environ Sci 6(2):91-95

Puglis HJ, Boone MD (2011) Effects of technical-grade active ingredient vs. commercial formulation of seven pesticides in the presence or absence of UV radiation on survival of green frog tadpoles. Arch Environ Contam Toxicol 60:145-155

Reitman S, Frankel S (1957) A colorimetric method for determination of serum glutamic oxaloacetic transaminase and serum glutamic pyruvic transaminase. Am J Clin Pathol 28:649-654

Saha S, Kaviraj A (2008) Acute toxicity of synthetic pyrethroid cypermethrin to some freshwater organisms. Bull Environ Contam Toxicol 80:49-52

Saha S, Kaviraj A (2009a) Effect of ambient temperature and daylight on the survival of freshwater catfish Heteropneustes fossilis (Bloch, 1974) exposed to cypermethrin. Environ Eng Sci 26(2):459-462

Saha S, Kaviraj A (2009b) Effects of cypermethrin on some biochemical parameters and its amelioration through dietary supplementation of ascorbic acid in freshwater catfish Heteropneustes fossilis. Chemosphere 74(19):1254-1258

Saha S, Kaviraj A (2013) Dietary ascorbic acid as a means to counter the stress of cypermethrin on the growth of freshwater catfish Heteropneustes fossilis. Toxicol Ind Health 29(5):468-473

Saravanan M, Karthika S, Malarvizhi A, Ramesh M (2011) Ecotoxicological impacts of clofibric acid and diclofenac in common carp (Cyprinus carpio) fingerlings: hematological, biochemical, ionoregulatory and enzymological responses. J Hazard Mater 195:188-194

Schmuck R, Pfleeger W, Grau R, Hollihn U, Fischer R (1994) Comparison of short-term aquatic toxicity: formulation vs active ingredients of pesticides. Arch Environ Contam Toxicol 26:240-250

Shruti SG, Raja IA, Tantarpale VT, Kulkarni KM (2011) Modulation in glycogen of the freshwater fish Ophiocephalus punctatus exposed to cypermethrin. Bioscan 6(1):129-130

Singh SK, Singh SK, Yadav RP (2010) Toxicological and biochemical alterations of cypermethrin (synthetic pyrethroids) against freshwater fish Colisa fasciatus at different season. World J Zool 5(1):25-32

Steffens RR (1989) Principles of fish nutrition. Ellis Horwood, Chichester

Tiwari S, Tiwari R, Singh A (2012) Impact of cypermethrin on fingerlings of common edible carps (Labeo rohita). Sci World. Article ID 291395. doi:10.1100/2012/291395

Tripathi G, Bandooni N (2011) Impact of alphamethrin on antioxidant defense (catalase) and protein profile of a catfish. Environmentalist 31:54-58

USEPA (2002) Methods for measuring the acute toxicity of effluents and receiving waters to freshwater and marine organisms. US Environment Protection Agency, Washington, DC. EPA-821-R-02-012

Vani T, Saharan N, Roy SD, Ranjan R, Pal AK, Siddaiah GM, Kumar R (2012) Alteration in haematological and biochemical parameters of Catla catla exposed to sub-lethal concentration of cypermethrin. Fish Physiol Biochem 38:1577-1584

Walter K, Schutt C (1974) Method of enzymatic analysis. Academic, New York

Yilmaz M, Gül A, Erbaşlı K (2004) Acute toxicity of alpha-cypermethrin to guppy (Poecilia reticulata Pallas, 1859). Chemosphere 56:381-385 